\title{
IDENTIFIKASI INDIKATOR KINERJA PENGELOLAAN PERIKANAN BUDIDAYA YANG BERSIFAT LESTARI
}

\author{
Sonny Koeshendrajana, Siti Hajar Suryawati, Subhechanis Saptanto dan Zahri Nasution")
}

\begin{abstract}
ABSTRAK
Tujuan riset ini adalah mengembangkan suatu indikator atau tolok ukur yang dapat digunakan untuk mengevaluasi pembangunan perikanan budidaya yang bersifat lestari (sustainable aquaculture development) yang relevan dengan situasi dan kondisi di Indonesia. Riset dilakukan pada tahun 2003. Metoda 'desk study' digunakan dalam riset ini. Metoda riset yang digunakan tersebut bersifat eksploratif analitik dengan memanfaatkan data sekunder dan literatur. Acuan utama yang digunakan dalam pendekatan ini adalah Code of Conduct Responsible Fisheries, khususnya perikanan budidaya, sistem referensi pembangunan berkelanjutan (Sustainable Development Reference System (SDRS) dan Rapid Apraisal for Fisheries (RAPFISH). Hasil kajian yang diperoleh pada studi ini adalah berupa perumusan kelompok indikator penting kedalam 5 kelompok, yaitu: teknologi, ekonomi, sosial, ekologi dan pengaturan. Hasil kajian memberikan saran pertimbangan bahwa dukungan aspek legal berupa hukum dan perundangan diperlukan agar indikator yang disusun dapat dikembangkan dan dimanfaatkan lebih lanjut secara konsisten dan bijaksana.
\end{abstract}

ABSTRACT: Identification of performance's indicators sustainable aquaculture development. By: Sonny Koeshendrajana, Siti Hajar Suryawati, Subhechanis Saptanto and Zahri Nasution

The objective of this research was to develop indicators enable to be used to evaluate sustainable aquaculture development relevant with condition and situation in Indonesia. Research was carried out in the year 2003. A study desk method was used in this study. The method used was analytically explorative using secondary data and relevant literatures. The main references used in this approach were the Code of Conduct Responsible Fisheries (CCRF), especially for aquaculture, Sustainable Development Reference System (SDRS) and Rapid Appraisal for Fisheries (RAPFISH). Results of the research identify formulation of important group of indicators, namely: technology, economics, social, ecology and governance. The results suggest that the indicators identified have to have the legal aspect in terms of law and regulation for further development and application consistently and wisely.

KEYWORDS: performance indicator, sustainable development, aquaculture

\section{PENDAHULUAN}

Indikator adalah unit informasi yang menggambarkan terjadinya sesuatu dalam sistem yang lebih besar ${ }^{1}$. Indikator merefleksi nilai-nilai yang dianggap penting dalam menentukan perubahan perilaku manusia dalam mengelola suatu sumberdaya. Indikator atau tolok ukur diperlukan sebagai pedoman untuk menilai sejauh mana keberhasilan pengelolaan/ pembangunan perikanan budidaya ditinjau dari konsepsi pembangunan yang bersifat lestari. Urgensi hasil kegiatan riset seperti ini adalah untuk mengembangkan suatu pendekatan tentang konsepsi pembangunan perikanan budidaya yang berkelanjutan yang bersifat kontekstual, sesuai dengan sistem lingkungan, sosial budaya, ekonomi dan politik. Lebih lanjut, hasil kegiatan riset ini dapat bermanfaat sebagai dasar atau acuan bagi perumusan kebijakan dan evaluasi secara akurat sebagai amanat Undangundang, Propenas maupun Renstra. Isu penting terkait di dalamnya adalah adanya tuntutan perubahan paradigma pembangunan ke arah pelibatan partisipasi masyarakat secara lebih aktif, sejalan tuntutan dan persyaratan era giobalisasi, implementasi kebijakan otonomi daerah dan pemanfaatan sumberdaya kelautan dan perikanan secara optimal dan berkelanjutan.

Studi berkaitan dengan identifikasi, penentuan ataupun penyusunan indikator kinerja pengelolaan sumberdaya yang bersifat lestari telah dilakukan oleh beberapa ilmuwan, antara lain : Ruitenbeek and Cartier (1998); Chesson and Clayton (2000); Garcia \& Staples (2000); Garcia et al., (2000); Pitcher \& Preikshot (2001). Di lain pihak, studi berkaitan dengan topik sejenis tersebut di atas pada sumberdaya perikanan

\footnotetext{
-) Peneliti pada Pusat Riset Pengolahan Produk dan Sosial Ekonomi Kelautan dan Perikanan
} 
budidaya belum banyak diungkapkan. Oleh karena itu, makalah ini dimaksudkan untuk mengembangkan suatu indikator atau tolok ukur yang dapat digunakan untuk mengevaluasi pembangunan perikanan budidaya yang bersifat lestari (sustainable aquaculture development) yang relevan dengan situasi dan kondisi di Indonesia.

\section{METODE}

Secara umum metoda yang digunakan dalam penelitian ini adalah metoda 'desk study'. Metoda desk study yang digunakan bersifat eksploratif analitik dengan memanfaatkan data dan informasi yang telah terdokumentasi. Hakekat metoda yang digunakan adalah melakukan kajian dokumen-dokumen yang mengupas isu terkait dengan pembangunan perikanan budidaya yang berkelanjutan dan melakukan pertemuan dalam bentuk semiloka untuk menampung pemikiran tenaga ahli (expert) terkait konteks tersebut. Tahapan riset yang dilakukan adalah sebagai berikut (1) melakukan dokumentasi dan kajian komparatif indikator-indikator yang pernah dikembangkan oleh negara lain berkaitan dengan isu keberlanjutan di bidang periknanan dan non-perikanan; (2) melakukan pertemuan dalam bentuk semiloka untuk mendapatkan masukan dari para ahli terkait dengan konteks tersebut yang relevan dengan situasi dan kondisi di Indonesia; dan (3) melakukan sintesa dan rumusan konsepsi indikator pembangunan perikanan budidaya yang bersifat berkelanjutan mengacu pada Code of Conduct Responsible Fisheries (CCRF) khususnya perikanan budidaya, sistem referensi pembangunan berkelanjutan (Sustainable Development Reference System, SDRS) dan Rapid Apraisal for Fisheries (RAPFISH).

\section{HASIL DAN BAHASAN}

Identifikasi, penentuan atau penyusunan indikator kinerja pengelolaan perikanan budidaya diawali dengan eksplorasi kegiatan sejenis dan pemahaman struktur perikanan budidaya. Selanjutnya dikembangkan suatu kriteria yang dapat dijadikan sebagai indikator kinerja suatu pembangunan atau pengelolaan sumberdaya perikanan budidaya yang bersifat lestari (berkelanjutan), baik sebagai suatu dimensi ataupun sebagai suatu atribut. Beberapa dasar pertimbangan dan urgensi indikator kinerja pembangunan perikanan budidaya yang berkelanjutan akan diuraikan pada topik hasil dan pembahasan pada tulisan ini.
Dewasa ini, kondisi perikanan dunia telah menjadi suatu sektor industri pangan yang berkembang secara dinamis dalam pengertian bahwa telah terjadi perubahan dari pemanfaatan perikanan sebagai sumber protein hewani secara subsisten menjadi suatu komoditas komersial yang dapat dimanfaatkan secara langsung atau melalui perubahan produk yang bernilai ekonomis (economically-value-added product). Hal ini berdampak pada intensitas pemanfaatan sumberdaya perikanan yang tersedia. Sebagai konsekuensi, dampak yang terlihat dengan cepat adalah suatu fenomena yang menunjukkan bahwa banyak sumberdaya perikanan yang telah menunjukkan gejala penurunan produktivitas. Praktek eksploitasi perikanan yang ada tidak mampu menjamin secara berkelanjutan (lestari) pemanfaatan sumberdaya alam yang ada. Adanya tanda-tanda nyata dari 'over-fishing', modifikasi ekosistem, kerugian ekonomi yang nyata serta konflik pengelolaan dan perdagangan ikan telah mengancam kelestarian sumberdaya perikanan jangka panjang serta mengancam kontribusi sektor perikanan terhadap penyediaan pangan. Sejak 1991 FAO komisi perikanan telah merekomendasikan suatu pendekatan pengelolaan perikanan yang meliputi konservasi sumberdaya alam dan lingkungan dengan memperhatikan pertimbangan manfaat sosial dan ekonomi (Anon., 1997a; 1997c). Khusus untuk perikanan budidaya, pendekatan yang digunakan disini mengacu hasil-hasil yang tercantum dalam referensi-referensi, antara lain adalah Anon., (1997b), Ruitenbeek \& Cartier (1998), Garcia \& Staples (2000) dan Pitcher \& Preikshot (2001). Namun demikian, keputusan-keputusan terkait dengan konservasi dan pengelolaan perikanan harus didasarkan pada buktibukti ilmiah, memperhatikan pengetahuan lokal (local knowledge) menyangkut sumberdaya dan habitatnya serta faktor-faktor lingkungan, ekonomi dan sosial yang relevan.

Pendekatan yang digunakan dalam penentuan dan pengukuran indikator kinerja pembangunan perikanan mengacu pada konsepsi pembangunan berkelanjutan. Konsep pembangunan berkelanjutan mengandung suatu pengertian yang luas; sedangkan pembanguan perikanan merupakan salah satu kegiatan usaha yang dapat memberikan kontribusi terhadap terwujudnya konsep pembangunan yang berkelanjutan. Prinsip-prinsip pembangunan atau pengelolaan sumberdaya perikanan yang berkelanjutan sebenarnya telah diupayakan sejak pencetusan UNCLOS (1982), United Nation Imple-

\footnotetext{
Pengertian indikator dan urgensinya, antara lain dapat dilihat pada Ruitenbeek \& Cartier (1998), Chesson \& Clayton (2000), Garcia \& Staples (2000), Garcia et al. (2000), Pitcher \& Preikshot (2001), Dahuri (2002) serta Haryadi \& Setiawan (2002).
} 
menting Agreement on Straddling Stock and Highly Migratory Stock (UNIA) tahun 1995 dan FAO Code of Conduct for Responsible Fisheries tahun 1995 (FAO, 2001) serta beberapa konvensi maupun protokol lainnya. Secara spesifik, konsepsi pembangunan perikanan yang berkelanjutan dikembangkan mengikuti konvensi-konvensi tersebut di atas dan konvensi berkaitan dengan sertifikasi pengelolaan perikanan (ISO 14000).

Meskipun pembangunan berkelanjutan merupakan suatu konsepsi yang luas, secara garis besar dalam konteks perikanan budidaya disarikan oleh Garcia et al. (2000) sebagai berikut: (a) Terjaminnya keamanan pangan bagi penduduk dunia; (b) Terciptanya suatu operasional kegiatan pembudidayaan ikan serta pengolahannya yang bersifat kompetitif dan menguntungkan; (c) Terjaminnya keberlanjutan sumberdaya yang dapat mendukung kegiatan perikanan dalam jangka panjang; dan (d) Terpeliharanya tingkat kesehatan dan kesatuan ekosistem pada sumberdaya tersebut untuk pemanfaat (uses) dan pengguna (users) yang lain, termasuk didalamnya keanekaragaman hayati, ilmu pengetahuan, nilai intrinsik, struktur trophic dan kegunaan ekonomi lainnya seperti pariwisata dan rekreasi.

Pada hakekatnya, pembangunan kelautan dan perikanan mengacu pada pembangunan berkelanjutan berbasis sumberdaya. Tiga komponen utama pada pembangunan berkelanjutan atau 'sustainable development', adalah sebagai berikut (Chesson \& Clayton (1998); Garcia \& Staples (2000); Garcia et al. (2000)): (a) Keberlanjutan pada berbagai sumberdaya pada lingkungan tertentu; (b) Kepuasan kebutuhan sosial dan ekonomi individu maupun masyarakat, dan; (c) Pengelolaan perubahan yang diperlukan pada aspek institusi dan teknologi.

Berdasarkan komponen tersebut di atas, Garcia \& Staples (2000) mengembangkan prinsip-prinsip pengelolaan yang dapat dijadikan dasar pengukuran indikator sebagai berikut:

1. Sumberdaya alam sebagai dasar seharusnya dikonservasi dan lingkungan sumberdaya alam yang ada dipertahankan kualitasnya. Sejalan dengan pemikiran di atas, dikembangkan 2 prinsip pengelolaan atau pembangunan, yakni : (a) Karakteristik sumberdaya alam yang ditargetkan agar dipertahankan pada tingkat eksploitasi tertentu sehingga mampu di eksploitasi secara kontinu dan dapat pulih dengan sendirinya; dan (b) Kondisi lingkungan agar diproteksi, dipertahankan dan dikembangkan ke arah produktivitas yang berkelanjutan.
2. Kebutuhan aspek sosial dan ekonomi dari individu dan masyarakat perlu dipenuhi secara berkelanjutan, baik untuk kebutuhan saat ini maupun saat mendatang. Berdasarkan pemikiran tersebut, dikembangkan 2 prinsip pengelolaan atau pembangunan, yakni : (a) Terpenuhinya kebutuhan manusia terhadap akses pada kualitas pangan yang tinggi, kesempatan kerja, pendapatan dan rekreasi dan nilai-nilai sosial serta budaya; dan (b) Kondisi ekonomi dari sektor perikanan (dalam hal insentif, biaya, pendapatan dan harga) agar konduksif pada jangka panjang.

3. Sistem pengelolaan yang efektif agar diterapkan sesuai dengan kebutuhan kelembagaan dan teknologi yang diperlukan. Berdasarkan pemikiran tersebut, dikembangkan 3 prinsip pengelolaan atau pembangunan, yakni : (a) Tujuan dari pembangunan dan strategi pengelolaan harus sejalan dengan prinsip konservasi sumberdaya dan lingkungan serta dapat memuaskan kebutuhan manusia; (b) Kelembagaan pengelolaan (sistem organisasi, perencanaan dan instrumen yang diperlukan, hak kepemilikan dan pengawasan) harus menunjukan pengelolaan yang efektif untuk mencapai tujuan yang ditetapkan; dan (c) Teknologi yang digunakan harus kompatibel dengan kemampuan mempertahankan sumberdaya dan lingkungan, baik dalam hal kapasitas ekspioitasi, selektivițas, dampak langsung maupun tidak langsung terhadap habitat, limbah buangan dan polusi.

\section{Pemahaman Struktur Perikanan Budidaya}

Perikanan budidaya atau akuakultur merupakan suatu sistem produksi pangan yang paling cepat tumbuh (Anon., 1997c). Pengertian perikanan budidaya seperti yang dicetuskan oleh FAO adalah suatu usaha budidaya organisme akuatik termasuk ikan, moluska, krustase dan tumbuhan akuatik. Kegiatan usaha budidaya mengandung pengertian adanya suatu intervensi dalam pemeliharaan untuk meningkatkan produksi, antara lain dalam bentuk pengolahan lahan, penebaran benih, pemberian pakan dan perlindungan dari pemangsa. Usaha budidaya juga mengandung pengertian bahwa hak kepemilikan usaha ini nyata, baik bersifat perorangan maupun badan usaha.

Kegiatan perikanan budidaya mencakup suatu kisaran yang sangat luas, baik menyangkut jenis ikan (species) yang dibudidayakan, lingkungan sumberdaya yang digunakan, sistem budidaya maupun pengelolaannya. Hal ini secara implisit 
memberikan banyak peluang bagi upaya peningkatan produksi pangan dan pendapatan bagi berbagai kelompok masyarakat, baik di pedesaan maupun pinggiran perkotaan. Namun demikian, di dalam sistem produksi tersebut terkandung suatu potensi konflik, baik berasal dari dalam maupun dari luar sistem produksi budidaya ikan itu sendiri. Beberapa potensi permasalahan terkait yang dimaksud, antara lain adalah: keterbatasan sumberdaya lahan dan ketersediaan air, penurunan mutu lingkungan, hak kepemilikan dan dukungan kelembagaan serta aspek legal.

Secara ekonomi, kendala maupun permasalahan utama pada pengelolaan perikanan budidaya adalah berkaitan dengan adanya dua bentuk eksternalitas ${ }^{2}$, yakni : (a) Eksternalitas yang ditimbulkan oleh suatu kegiatan produksi budidaya ikan itu sendiri atau kegiatan lain yang menyebabkan dampak yang tidak diharapkan, antara lain dalam bentuk pencemaran; dan (b) Eksternalitas yang ditimbulkan oleh adanya persaingan dalam hal akses terhadap sumberdaya lahan dan air yang terbatas.

Untuk mempelajari lingkup kegiatan perikanan budidaya, pendekatan yang dilakukan pada dasarnya mengikuti karakteristik atau struktur dari perikanan budidaya itu sendiri. Dalam hal ini, dapat diklasifikasikan menurut eksistensi tipe sumberdaya yang ada, yaitu: (a) sumberdaya perairan tawar (freshwater aquaculture); (b) sumberdaya perairan payau (brackishwater aquaculture); dan (3) sumberdaya perairan laut (marine aquaculture). Pemahaman struktur perikanan budidaya juga dapat diklasifikasikan menurut lingkungan/sistem wadah budidaya, yang dapat dikelompokkan menjadi 5 kelompok, yakni : (a) kolam (pond); (b) karamba (cage); (c) tangki/drum/akuarium (tank); (d) tancap (pen); dan (e) sawah (ricefield).

Klasifikasi menurut sistem budidaya dapat dikelompokkan kedalam : (a) monokultur; (b) polikultur; dan (c) budidaya terpadu. Pengelompokkan menurut sistem pengelolaan atau tingkat teknologi/intensitas usaha budidaya ikan dapat dikategorikan sebagai : (a) budidaya secara intensif; (b) budidaya secara semiintensif; dan (c) budidaya secara ekstensif atau tradisional. Secara diagramatik, struktur perikanan budidaya tersebut di atas dapat diilustrasikan secara sederhana seperti tertera pada Gambar 1

Eksplorasi lebih mendalam dapat saja dilakukan, antara lain, menurut klasifikasi jenis ikan yang dibudidayakan (misalnya ikan mas, nila dan lele untuk lingkungan air tawar; ikan bandeng, nila dan udang windu untuk lingkungan air payau, dan; ikan baronang, kerapu dan tuna untuk lingkungan air laut) dan segmen usaha budidaya (pembenihan, pendederan dan pembesaran). Tetapi, dalam makalah ini, untuk penyederhanaan pembahasan, klasifikasi tersebut tidak diungkapkan secara eksplisit.

\section{Pengembangan Indikator Kinerja}

Telah diuraikan di muka bahwa 'indikator' mengandung pengertian sebagai suatu unit informasi yang menggambarkan terjadinya sesuatu dalam sistem yang lebih besar. Indikator merefleksi nilai-nilai yang dianggap penting dalam menentukan perubahan perilaku manusia dalam mengelola suatu sumberdaya. Urgensi suatu indikator adalah untuk meyakinkan atau membantu terciptanya suatu komunikasi secara jelas, terbuka (transparan), efektif dan dapat dipertanggungjawabkan terhadap berlakunya suatu pengelolaan sumberdaya alam yang sangat kompleks. Dengan demikian, indikator yang dimaksud haruslah mudah dipahami dengan cepat dan dapat merepresentasikan keadaan suatu tujuan yang telah ditentukan dari suatu pengelolaan. Indikator tersebut sedapat mungkin mampu menyederhanakan dan menyerasikan suatu keadaan baik pada skala global (nasional) ataupun regional (lokal) dari suatu praktek pengelolaan, baik pada tingkat identifikasi permasalahan, formulasi, implementasi maupun monitoring dan evaluasi suatu kebijakan. Meskipun indikator-indikator suatu kinerja pengelolaan dapat dimunculkan berdasarkan berbagai sudut pertimbangan, pendekatan umum yang telah disarankan oleh Garcia et al. (2000) dan banyak dilakukan oleh para peneliti lain adalah suatu pendekatan yang disebut sebagai 'rujukan bagi sistem referensi pembangunan berkelanjutan' (Sustainable Development Reference System, SDRS).

Berdasarkan pendekatan SDRS tersebut di atas, terdapat 5 tahapan kerja yang harus dilakukan, yakni (a) Pernyataan ruang lingkup dari SDRS; (b) Pengembangan kerangka kerja yang disepakati terhadap komponen-komponen di dalam sistem; (c) Pernyataan adanya suatu kriteria, tujuan, indikator potensial dan nilai referensi; (d) Pemilihan kumpulan atau kelompok indikator dan nilai referensi; dan (e) Pernyataan metoda analisis (penggabungan) dan interpretasinya (visualisasinya)

Mengacu pada indikator kinerja yang biasa digunakan dalam melihat keberlanjutan pengelolaan

\footnotetext{
2 Pengertian eksternalitas lebih detail dapat dilihat pada Conrad \& Clark (1987), Anon., (1997b; 1997c), Hartwick \& Olewiler (1998)
\& Fauzi (2004).
} 


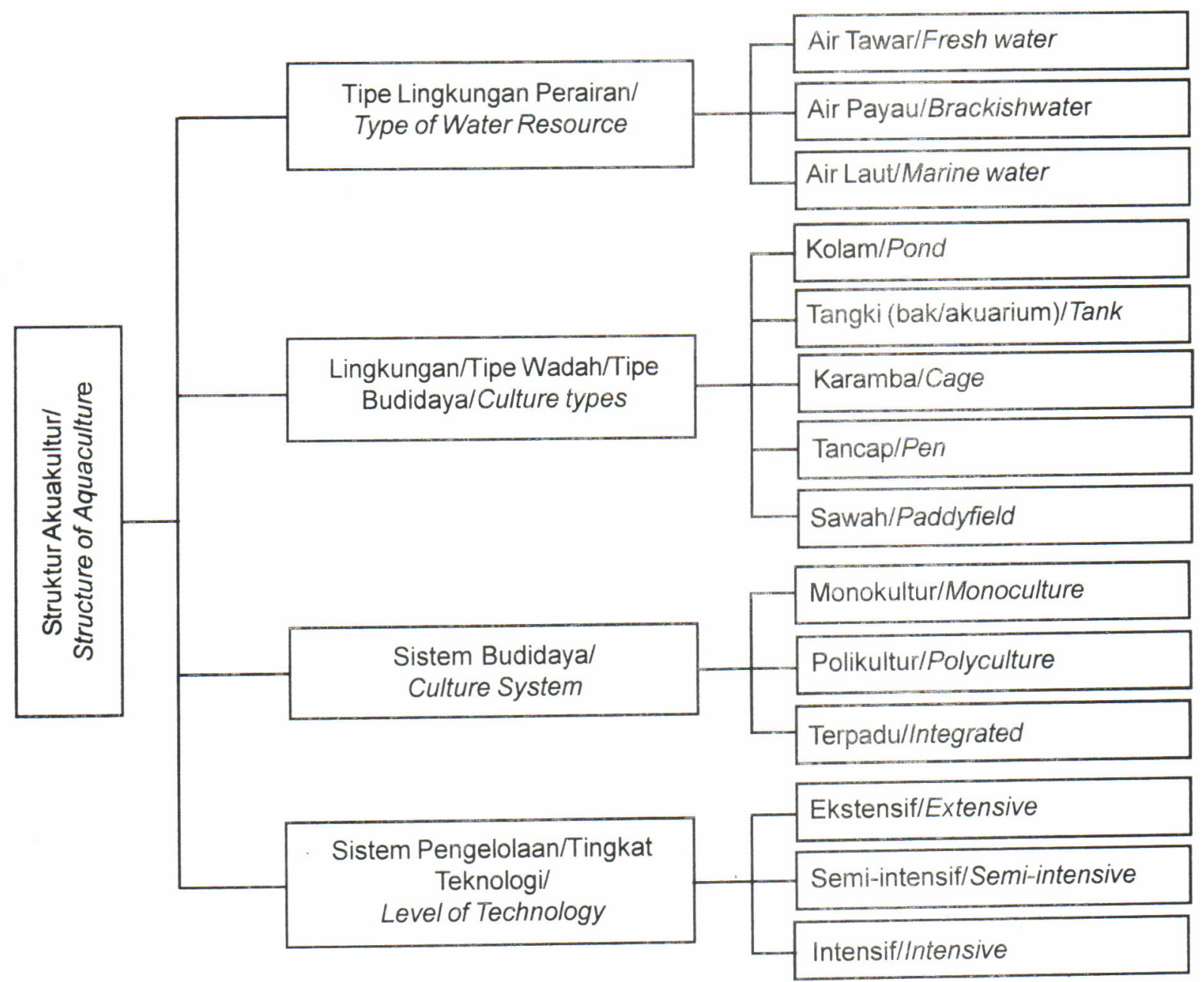

Gambar 1. Struktur budidaya menurut klasifikasi lingkungan, sistem budidaya dan pengelolaannya.

Figure 1. Structure of aquaculture according to environmental classification, culture system and its management.

perikanan tangkap, indikator kinerja yang disusun haruslah dapat membantu mengkomunikasikan secara jelas (transparan), efektif dan dapat dipertanggungjawabkan dalam aspek pengelolaan sumberdaya (FAO, 2001 dalam Taryono, 2003). Indikator-indikator yang dipertimbangkan hendaklah mengacu pada suatu alat rujukan bagi sistem referensi pembangunan berkelanjutan (Sustainable Development Reference System, SDRS); yang mampu menyediakan informasi yang saling melengkapi dalam dua cara, yakni : (a) Indikator tersebut memberikan data dan informasi pada skala tertentu; dan (b) Informasi tersebut mampu memberikan data untuk dapat di analisis lebih lanjut dan dalam kerangka kerja yang lebih keras.

Penilaian kelestarian sumberdaya konvensional di dasarkan pada parameter yang dimiliki oleh dimensi biologi dan ekologi sebagai indikator. Indikator- indikator yang ditunjukkan oleh parameter dari kedua dimensi tersebut ternyata belum dapat memuaskan pihak penentu kebijakan maupun pelaku praktis usaha perikanan. Perkembangan terakhir menunjukkan adanya suatu pendekatan yang bersifat multi aspek dalam mengukur kinerja pengelolaan suatu sumberdaya yang bersifat lestari. Pendekatan tersebut mencakup dimensi biologi, ekologi, ekonomi, sosial, teknologi dan etika (Garcia et al., 2000; Pitcher \& Preikshot, 2001). Hal ini sejalan dengan perkembangan paradigma suatu proses pembangunan bahwa dalam melakukan analisis mengenai perkembangan pembangunan berkelanjutan, diperlukan suatu indikator atau tolok ukur yang mengandung pengertian sesuai dengan tujuan analisis yang lebih luas yang mencakup dimensi ekologis, sosial, ekonomi dan kelembagaan. Berbeda dengan dimensi biologi dan ekologi yang ditunjukkan oleh 
penetapan indikator kelestarian yang sifatnya relatif baku, dimensi lain seperti ekonomi, sosial, teknologi dan etika bersifat dinamis sesuai dengan spesifikasi sumberdaya perikanan yang ada.

Setelah tujuan dan ruang lingkup dari SDRS ditentukan, maka dapat dikembangkan suatu kerangka kerja yang menghubungkan antara suatu indikator dengan kondisi kelestarian sumberdaya yang diamati. Kerangka kerja yang secara terstruktur menunjukkan dimensi-dimensi yang relevan dari pembangunan berkelanjutan, antara lain sosial, ekonomi, lingkungan dan kelembagaan dapat dikelompokkan menurut klasifikasi tertentu seperti terlihat pada Tabel 1. Dalam hal ini, beberapa indikator untuk mengukur kondisi kelestarian sumberdaya telah dikembangkan sesuai dengan paradigma kerangka sistem referensi pembangunan berkelanjutan.

Untuk dapat meningkatkan kemampuan komunikasi dan pemahaman dimensi keberlanjutan masing-masing dimensi tersebut harus mempunyai

Tabel 1. Dimensi subsistem kehidupan dan lingkungan dari sistem referensi pembangunan berkelanjutan

Table 1. Dimension of life-style and environmental subsystem of the sustainable development reference system

\begin{tabular}{|c|c|c|c|c|}
\hline $\begin{array}{c}\text { Kerangka Umum } \\
\text { Pembangunan }\end{array}$ & & Dimensi/Dir & imen & sion \\
\hline $\begin{array}{l}\text { General framework for } \\
\text { sustainable development }\end{array}$ & & $\begin{array}{l}\text { Subsistem Kehidupan/ } \\
\text { Life-style subsystem }\end{array}$ & & $\begin{array}{l}\text { Subsistem Lingkungan/ } \\
\text { Enviromental subsystem }\end{array}$ \\
\hline $\begin{array}{l}\text { 1. Definisi FAO tentang } \\
\text { Pembangunan } \\
\text { Berkelanjutan/FAO } \\
\text { definision on sustainable } \\
\text { development }\end{array}$ & a. & $\begin{array}{l}\text { Sumberdaya perikanan } \\
\text { budidaya/Aquaculture resource } \\
\text { Kelembagaan//nstitution } \\
\text { Penduduk Masyarakat/Community }\end{array}$ & a. & $\begin{array}{l}\text { Lingkungan/Environment } \\
\text { Teknologi/Technology }\end{array}$ \\
\hline $\begin{array}{l}\text { 2. Petunjuk Pelaksanaan } \\
\text { Budidaya Perikanan yang } \\
\text { bertanggungjawab dari } \\
\text { FAO/FAO Code of Conduct } \\
\text { for Responsible Fisheries - } \\
\text { Aquaculture }\end{array}$ & a. & $\begin{array}{l}\text { Praktek Budidaya/Aquaculture } \\
\text { practices } \\
\text { Integrasi kedalam pengelolaan } \\
\text { pengembangan tata ruang pesisir } \\
\text { terpadu//ntegration to the } \\
\text { management of area development } \\
\text { Pengembangan } \\
\text { Budidaya/Aquaculture } \\
\text { development }\end{array}$ & b. & $\begin{array}{l}\text { Pengelolaan sumberdaya } \\
\text { perikanan } \\
\text { budidaya/Management of } \\
\text { aquaculture resource } \\
\text { Penanganan pascapanen } \\
\text { dan pemasaran/Post } \\
\text { hanest and marketing } \\
\text { practices } \\
\text { Penelitian perikanan } \\
\text { budidaya/Aquaculture } \\
\text { research }\end{array}$ \\
\hline
\end{tabular}
3. Respon-Pernyataan- Tekanan/Pressure-State- Response (PSR)
a. Tekanan/Pressure
b. Pernyataan/State

a. Respon/Response

\begin{tabular}{|c|c|c|}
\hline $\begin{array}{l}\text { 4. Komisi Kerja Indikator } \\
\text { Pembangunan Perikanan } \\
\text { Budidaya } \\
\text { Berkelanjutan/Working } \\
\text { commission on sustainable } \\
\text { aquaculture development }\end{array}$ & $\begin{array}{l}\text { a. Lingkungan Sosial/Social } \\
\text { environment }\end{array}$ & $\begin{array}{ll}\text { a. Ekonomi/Economics } \\
\text { b. Kelembagaan//nstitutions }\end{array}$ \\
\hline
\end{tabular}

Sumber: Diadopsi dari Garcia et al. (2000)/Source: Adopted from Garcia et al. (2000) 
Tabel 2. Beberapa contoh atribut dan dimensi pembangunan berkelanjutan sumberdaya perikanan tangkap Table 2. Various example of attributes and dimensions of sustainable development for capture fisheries resource

\begin{tabular}{|c|c|c|}
\hline $\begin{array}{l}\text { Nomorl } \\
\text { Number }\end{array}$ & Dimensi/Dimension & Atribut/Atribut \\
\hline \multirow[t]{9}{*}{1} & Ekonomi/Economics & Volume produksi/Volume of production \\
\hline & & Nilai produksi/Value of production \\
\hline & & $\begin{array}{l}\text { Kontribusi perikanan dalam PDB/Fishery } \\
\text { contribution to GDP }\end{array}$ \\
\hline & & $\begin{array}{l}\text { Nilai ekspor perikanan (dibandingkan dengan total } \\
\text { nilai eksport)/Fishery export (comparing to the total } \\
\text { export) }\end{array}$ \\
\hline & & $\begin{array}{l}\text { Investasi dalam armada perikanan dan fasilitas } \\
\text { pengelolaan/Investment on fishing fleet and } \\
\text { management facilities }\end{array}$ \\
\hline & & Pajak dan subsidi/Tax and subsidy \\
\hline & & Tenaga kerja/Labour \\
\hline & & Pendapatan/Income \\
\hline & & Penerimaan bersih /Net revenue \\
\hline \multirow[t]{7}{*}{2} & Sosial/Social & Partisipasi angkatan kerja/Labour participation \\
\hline & & Demografi/Demography \\
\hline & & Pendidikan/Education \\
\hline & & Konsumsi protein/Consumption of protein \\
\hline & & Tradisi (budaya)/custom (culture) \\
\hline & & Hutang/debt \\
\hline & & $\begin{array}{l}\text { Distribusi gender dalam pengambilan } \\
\text { keputusan/Gender distribution on the decision } \\
\text { making }\end{array}$ \\
\hline \multirow[t]{4}{*}{3} & Ekologi/Ecology & Keanekaragaman hayati/Biodiversity \\
\hline & & $\begin{array}{l}\text { Dampak terhadap species lain/impact on other } \\
\text { species }\end{array}$ \\
\hline & & Tingkat Pemanfaatan/Level of exploitation \\
\hline & & Efek terhadap habitat//mpact on habitat \\
\hline \multirow[t]{5}{*}{4} & Pengelolaan/Management & Akses pengelolaan/Access to management \\
\hline & & Hak kepemilikan/Property Rights \\
\hline & & $\begin{array}{l}\text { Keterbukaan dan partisipasi/Accountability and } \\
\text { participation }\end{array}$ \\
\hline & & $\begin{array}{l}\text { Kemampuan untuk mengelola/Management } \\
\text { capacity }\end{array}$ \\
\hline & & $\begin{array}{l}\text { Tatalaksana pengelolaan yang baik/Good } \\
\text { Governance }\end{array}$ \\
\hline
\end{tabular}

Sumber: Diadopsi dan dimodifikasi dari 'FAO: Technical Guidelines for Responsible Fisheries No. 8, Indicator for Sustainable Development of Marine Capture Fisheries

Source: Modified and adopted from the FAO: Technical Guidelines for Responsible Fisheries No. 8, Indicator for Sustainable Development of Marine Capture Fisheries 
kriteria yang jelas. FAO telah mengembangkan beberapa atribut untuk masing-masing dimensi dalam SDRS-nya, seperti terlihat pada Tabel 2.

Fakta-fakta teoretis maupun kajian literatur yang dapat ditelusuri sampai saat ini memperlihatkan bahwa belum ada kriteria yang dapat dijadikan sebagai tolok ukur atau indikator kinerja pengelolaan perikanan budidaya secara tepat sesuai dengan kebutuhan pengguna, baik bagi penentu kebijakan maupun praktisi lapang. Bertolak dari fenomena tersebut, maka pelaksanaan kegiatan riset identifikasi, penentuan atau pengukuran indikator kinerja pengelolaan perikanan budidaya yang telah dilakukan di awali dengan pertemuan dalam bentuk semilokakarya (small-workshop) yang pada intinya membahas tahapan pelaksanaan riset penentuan/ penyusunan indikator kinerja pengelolaan perikanan budidaya

Hasil pertemuan pertama memberikan saran dan pertimbangan akan keterbatasan studi sejenis yang terkait dengan pengelolaan perikanan budidaya, maka tahapan pertama yang perlu dilakukan adalah melakukan literature review berkaitan dengan penentuan ruang lingkup perikanan budidaya dan penentuan pendekatan yang dapat digunakan dalam identifikasi indikator kinerja perikanan budidaya.

\section{Tujuan dan Ruang Lingkup Indikator Kinerja}

Secara umum tujuan identifikasi, penentuan atau penyusunan indikator kinerja pembangunan perikanan budidaya adalah untuk mendapatkan suatu referensi yang dapat dijadikan suatu kriteria dalam melakukan monitoring dan evaluasi status keberlanjutan pengelolaan sumberdaya perikanan budidaya. Ruang lingkup indikator kinerja di arahkan untuk pencapaian visi dan misi departemen, dan ruang lingkupnya dapat ditelusuri melalui dampak suatu aktivitas pengelolaan perikanan budidaya pada masyarakat dan lingkungan. Secara ringkas, dampak suatu kegiatan budidaya ikan pada masyarakat atau manusia dapat diidentifikasi melalui pengaruhnya terhadap ketahanan pangan (food security), penyediaan kesempatan kerja (employment opportunity), pendapatan (income) dan pola hidup masyarakat (lifestyle) serta lingkungan (environment). Mengacu pada Petunjuk Pembangunan Akuakultur (Anon., 1997c), kondisi ketahanan pangan dapat tercapai apabila masyarakat mempunyai akses fisik dan ekonomi pada pangan yang cukup, sehat dan bergizi untuk memenuhi kebutuhan pangan mereka dan preferensi pangan untuk kehidupan yang aktif dan sehat sepanjang waktu.

Dampak suatu kegiatan budidaya ikan pada lingkungan dapat diidentifikasi melalui pengaruhnya terhadap perairan itu sendiri, biodiversitas (biodiversity), keragaman genetik (genetic diversity) serta aspek lain, seperti sumberdaya lahan dan air untuk peruntukan lain. Pengertian biodiversitas pada konteks ini mengandung pengertian tetap terpeliharanya keanekaragaman hayati sebagai akibat pemilihan jenis ikan (species) yang dipelihara dan ditempatkan di suatu lokasi budidaya tertentu. Pengertian terpeliharanya keanekaragaman hayati secara sederhana dapat diartikan bahwa dalam pengelolaan budidaya ikan, ada upaya-upaya menghindari hilangnya suatu species/jenis ataupun strain/varietas ikan. Pengertian terpeliharanya keanekaragaman genetik secara sederhana dapat diartikan bahwa dalam pengelolaan budidaya ikan, ada upaya-upaya menghindari kawin kerabat (inbreeding), mempertahankan keutuhan stok dengan cara tidak melakukan hibridisasi stok, strain-strain atau speciesspecies yang berbeda, meminimumkan transfer stok yang berbeda secara genetik dan melakukan kajian keaneka ragaman genetik secara berkala. Secara sederhana, tujuan dan ruang lingkup indikator kinerja perikanan budidaya dapat diilustrasikan seperti pada Gambar 2

\section{Pengembangan Kerangka Kerja dan Identifikasi Kriteria}

Berdasarkan tujuan dan ruang lingkup penelitian kerangka kerja dalam bentuk dimensi dan kriteria yang dapat dikembangkan dapat dipaparkan seperti tercantum pada Tabel 3. Pada pemilihan kriteria biasanya dikembangkan berdasarkan' beberapa paparan konsepsi atau model yang memberikan ilustrasi bagaimana suatu sistem bekerja dan bagaimana elemen-elemen atau komponen-komponen dalam sistem tersebut saling berinteraksi. Oleh karena itu, sumbangan pemikiran dari para pakar yang sesuai dengan bidang keilmuan yang terkait dengan perikanan budidaya sangat dibutuhkan. Komponen penting dalam proses pengembangan kerangka kerja dan identifikasi kriteria ini adalah mengembangkan dan menyatakan suatu kumpulan tujuan pada masingmasing dimensi serta kriteria yang telah disusun yang dapat diterima oleh seluruh 'stakeholders'. Dalam kenyataannya, hal tersebut secara bertahap akan terdeteksi dengan sendirinya.

\section{Pemilihan Indikator Kinerja dan Penentuan Kriteria}

Meskipun tahapan tersebut di atas telah dapat dilakukan, komponen dan kriteria dalam bentuk lain masih memungkinkan dimunculkan. Tahapan selanjutnya adalah menentukan kriteria-kriteria yang dapat dijadikan acuan dalam pemilihan indikator yang telah diusulkan agar indikator tersebut bersifat efektif. 


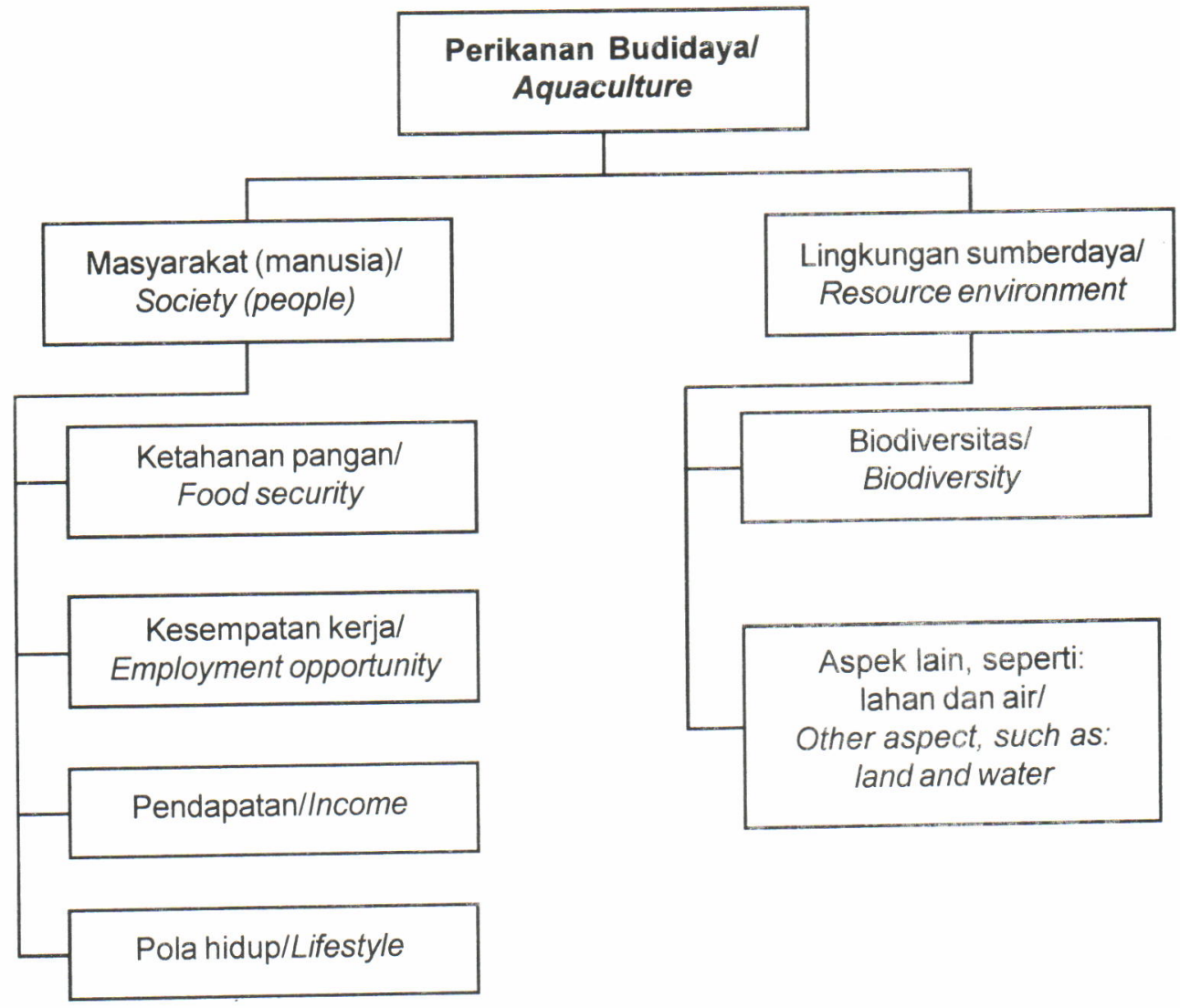

Gambar 2. Ruang lingkup pengaruh/dampak kegiatan pembangunan perikanan budidaya. Figure 2. Scope of aquaculture development influence/impact.

Beberapa kriteria yang dapat digunakan adalah sebagai berikut (Garcia \& Staples, 2000; Haryadi \& Setiawan, 2002):

(a) Prioritas atau relevan bagi penentuan kebijakan. Kebijakan akan menentukan arah tindakan yang harus diambil, maka indikator seharusnya memberikan informasi yang jelas bagi penentu kebijakan. Indikator seharusnya dapat memberikan dukungan informasi kepada penentu kebijakan untuk membuat peraturan yang mengarah kepada penentuan kualitas kesejahteraan masyarakat.

(b) Penggunaan praktis (praktikabilitas) atau fisibilitas dan relevan atau sesuai dengan kepentingan tertentu. Indikator seharusnya sesuai dengan persyaratan keberlanjutan. Persyaratan tersebut merupakan dasar terbentuknya kesejahteraan masyarakat di bidang sosial, ekonomi, kultural, dan kesehatan masyarakat.

(c) Mencerminkan nilai-nilai masyarakat. Indikator seharusnya dapat mencerminkan nilai-nilai yang dianggap penting oleh masyarakat sehingga masyarakat akan lebih tertarik untuk ikut memikirkannya dan sekaligus memberikan informasi yang diperoleh. Indikator yang dapat merangsang pemikiran tentang tindakan lebih lanjut dapat menjadi salah satu gambaran tentang efektivitas dari indikator tersebut.

(d) Dapat diukur meialui metoda statistik. Metoda statistik memungkinkan peneliti untuk membandingkan kondisi kesejahteraan masyarakat di suatu tempat dengan kondisi di tempat yang lain. Indikator-indikator yang sama diperbandingkan. Dari sana akan dapat diperoleh gambaran tentang kondisi kesejahteraan yang berbeda antar satu tempat dengan tempat yang lain. Jika ada tempat tertentu yang dipakai sebagai acuan untuk mengukur keberlanjutan maka akan dapat diperoleh informasi tentang kondisi di tempat-tempat lain jika dibandingkan dengan tempat yang diacu tadi. Namun demikian tidak semua indikator harus selalu diukur dengan angka. Indikator yang dapat merangsang pemikiran atau imajinasi tentang tindakan lebih 
Tabel 3. Dimensi dan indikator potensial yang dapat dikembangkan pada penentuan indikator kinerjapengelolaan perikanan budidaya berkelanjutan

Table 3. Dimension and potential indicator for developing a performance indicator of the sustainable aquaculture development

\begin{tabular}{|c|c|c|}
\hline $\begin{array}{l}\text { Tipe Kriterial } \\
\text { Type of criteria }\end{array}$ & $\begin{array}{c}\text { Dimensil } \\
\text { Dimension }\end{array}$ & $\begin{array}{c}\text { Indikator Potensial/ } \\
\text { Potential Indicator }\end{array}$ \\
\hline \multirow{6}{*}{$\begin{array}{l}\text { Tekanan terhadap } \\
\text { sumberdaya/ } \\
\text { Pressure on } \\
\text { resource }\end{array}$} & Teknologi/ & Tingkat Teknologi/Level of technology \\
\hline & Technology & Padat Penebaran/stocking density \\
\hline & & Benih Unggul/Higher quallity of seed \\
\hline & & Produktivitas/Productivity \\
\hline & & $\begin{array}{l}\text { Pakan/Feed } \\
\text { Penggunaan Antibiotik/Antibiotic used }\end{array}$ \\
\hline & & $\begin{array}{l}\text { Pengunaan Obat-obatan dan Pestisidal Medical and } \\
\text { Pesticides used }\end{array}$ \\
\hline \multirow{22}{*}{$\begin{array}{l}\text { Pernyataan } \\
\text { hubungan } \\
\text { sumberdaya dan } \\
\text { penggunal } \\
\text { State of resources } \\
\text { and users } \\
\text { relationship }\end{array}$} & Ekonomil & Kontribusi PDB/Contribution to GDP \\
\hline & Economic & Pendapatan pembudidaya/farmers' income \\
\hline & & $\begin{array}{l}\text { Produksi dan Nilai Produksi/Production and value of } \\
\text { production }\end{array}$ \\
\hline & & Nilai Ekspor/Export value \\
\hline & & Orvestasilinestirem \\
\hline & & \\
\hline & & Pajak dan Subsidi/Tax and subsidy \\
\hline & & Pasar/Market \\
\hline & Sosial/Social & Kesempatan Kerja/Labour opportunity \\
\hline & & Partisipasi Masyarakat/Community participation \\
\hline & & Status konflik/Conflict status \\
\hline & & Demografi/Demography \\
\hline & & Ketersediaan dan konsumsi ikan/Fish Consumption \\
\hline & & Pendidikan/Education \\
\hline & & Kesetaraan 'gender'/Gender participation \\
\hline & & Tradisi (budaya)/Custom (culture) \\
\hline & $\overline{E k o l o g i / E c o l o g y}$ & Biodiversitas/Biodiversity \\
\hline & & Kualitas lingkungan perairan/Quality of the water environment \\
\hline & & Tata ruang/Landscaping \\
\hline & & Pemanfaatan lahan/Land used \\
\hline & & $\begin{array}{l}\text { Dampak langsung terhadap lingkungan/Direct impact on } \\
\text { environment }\end{array}$ \\
\hline & & $\begin{array}{l}\text { Dampak tidak langsung terhadap lingkungan//ndirect impact } \\
\text { on environment }\end{array}$ \\
\hline \multirow{6}{*}{$\begin{array}{l}\text { Respon } \\
\text { pengelolaan/ } \\
\text { Management } \\
\text { Response }\end{array}$} & Pengaturan/ & Hak Kepemilikan/Property Rights \\
\hline & Govemance & Transparansi/Transparancy \\
\hline & & Kemitraan (partisipasi)/Partnership (participation) \\
\hline & & Kemampuan untuk Mengelola/Management capacity \\
\hline & & Regulasi/Regulation \\
\hline & & 'Compliance regime' \\
\hline
\end{tabular}


lanjut tanpa dengan angka, tetap diperlukan. Secara implisit, terkandung aspek akurasi dan ketepatan serta ada validitas ilmiah.

(e) Terpercaya (reliable) dan bersifat 'robust' terhadap ketidak pastian. Informasi yang ditunjukkan dalam indikator tersebut harus dapat meyakinkan orang. Sebagai contoh yang dapat diutarakan adalah alat pengukur berat badan (timbangan). Jika alat penunjuk tersebut memperlihatkan berat badan yang kurang dari sebenarnya, maka tindakan selanjutnya mungkin bukan sesuatu yang seharusnya dilakukan. Seharusnya yang dilakukan adalah mengurangi makan tetapi justru menambah jatah makanan. Timbangan tersebut tidak dapat dipercaya (unreliable)

(f) Kemampuan untuk menyampaikan suatu informasi. Indikasi tertariknya media lokal dapat dilihat dengan dipublikasikannya indikatorindikator sebagai alat ukur keberlanjutan serta dimanfaatkannya indikator-indikator tersebut untuk memonitor kualitas kesejahteraan masyarakat.

(g) Ketersediaan data dan dokumentasi yang cukup

(h) Kemudahan untuk dipahami.

(i) Waktu yang dibutuhkan dan efektifitas biaya.

(j) Dukungan aspek legal

\section{Analisis dan Intepretasi}

Pada tahap akhir, indikator kinerja yang diperoleh dapat disajikan sesuai dengan tingkatan keperluan ataupun dapat dilakukan analisis dan interpretasi lebih lanjut berkaitan dengan sistem yang sedang dimonitor dan dievaluasi.

\section{KESIMPULAN DAN SARAN}

1. Hasil kajian karakteristik atau struktur perikanan budidaya memberikan gambaran bahwa system produksi ikan tersebut dapat diklasifikasikan menurut berbagai sudut pandang. Klasifikasi struktur perikanan budidaya menurut tipe sumberdaya yang ada, dapat dikemukakan sebagai berikut: (a) sumberdaya perairan tawar (freshwater aquaculture); (b) sumberdaya perairan payau (brackishwater aquaculture); dan (3) sumberdaya perairan laut (marine aquaculture). Selain daripada itu, pemahaman struktur perikanan budidaya dapat diklasifikasikan menurut lingkungan budidaya, dalam hal ini dapat dikelompokkan menjadi 5 kelompok, yakni: (a) kolam (pond); (b) karamba (cage); (c) tangki/ drum (tank); (d) tancap (pen); dan (e) sawah (ricefield).
2. Klasifikasi menurut sistem budidaya dapat dikelompokkan kedalam: (a) monokultur; (b) polikultur, dan; (c) budidaya terpadu Pengelompokkan menurut sistem pengelolaan atau tingkat intensitas usaha budidaya ikan dapat dikategorikan sebagai (a) budidaya secara intensif; (b) budidaya secara semi-intensif; dan (c) budidaya secara ekstensif atau tradisional.

3. Dasar pemikiran yang digunakan dalam identifikasi penentuan atau penyusunan indikator kinerja pengelolaan perikanan budidaya adalah bahwa pengelolaan atau pembangunan tersebut bersifat berkelanjutan (sustainable development). Pengaruh aktivitas budidaya adalah pada aspek manusia (human) dan lingkungan sumberdaya (resource environment); sehingga, indikator yang dapat diidentifikasi sesuai dengan kerangka berfikir yang digunakan adalah berkaitan dengan dimensi-dimensi: teknologi, ekonomi, sosial, ekologi dan pengaturan.

4. Indikator potensial sesuai dengan dimensi atau domain tersebut, antara lain, adalah tingkat teknologi dan produktivitas (teknologi); kontribusi PDB, profitabilitas dan pasar (ekonomi); kesempatan kerja, partisipasi masyarakat dan status konflik (sosial); pemanfaatan lahan, biodiversitas dan dampak terhadap lingkungan (ekologi), dan regulasi, transparansi dan kemitraan (pengaturan).

5. Berbagai macam indikator kinerja telah dikembangkan dan dipraktekkan dalam lingkup perikanan budidaya. Hasil kajian, memberikan ilustrasi indikator kinerja pengelolaan sumberdaya perikanan budidaya bersifat komprehensif dan penting. Untuk kepentingan pengembangan lebih lanjut dan penerapannya di lapang, diperlukan dukungan aspek legal berupa hukum dan perundangan. Kemudian, pengujian lapang secara empiris kiranya perlu untuk mengetahui efektivitas pemanfaatannya dalam kerangka pembangunan perikanan.

\section{DAFTAR PUSTAKA}

Anonim. 1997a. Perikanan Darat (Inland Fisheries) Pedoman Teknis untuk Perikanan yang Bertanggungjawab. FAO Tech. Guidelines for Responsible Fisheries No. 6. Rome. 36 pp.

Anonim. 1997b. Pembangunan Akuakultur (Aquaculture Development). FAO Tech. Guidelines for Responsible Fisheries No. 5. Rome. 49 pp.

Anonim. 1997c. Pengelolaan Perikanan (Fisheries Management). FAO Tech. Guidelines for Responsible Fisheries No. 4. Rome. 93 pp

Butcher, J.G. 1995. Extending the Fronteir: The Marine Fisheries of Southeast Asia Since 1850. 
Callen, S.J. and Thomas, J.M. 1996. Environmental Economics and Management: Theory, Policy and Applications. IRWIN. Chicago.

Conrad, J.M. and Clark, C.W. 1987. Natural Resource Economics: Notes and Problems. Cambridge University Press. Cambridge. 231 pp.

Fauzi, A. 2004. Ekonomi Sumber Daya Alam dan Lingkungan: Teori dan Aplikasi. Penerbit PT Gramedia Pustaka Utama. Jakarta. 259 pp.

Garcia, S.M. and Staples, D.J. 2000. Sustainability reference systems and indicators for responsible marine capture fisheries: A review of concepts and elements for a set of guidelines. Marine and Freshwater Research, 51 : 385-426.

Garcia, S.M., Staples, D.J. and Chesson, J. 2000. The FAO Guidelines for the development and use of indicators for sustainable development of marine capture fisheries and an Australian example of their application. Ocean and Coastal management. 43 : 537 556.

Chesson, J. and Clayton, H. 1998. A Framework For Assessing Fisheries With Respect To Ecologically Sustainable Development. Bureau of Resource Science, Fisheries Resource Branch: Canberra.

Dunn, W.N. 2000. Pengantar Analisis Kebijakan Publik. Edisi Kedua. Edisi Bahasa Indonesia. Gajahmada university Press. Yogyakarta.
Hartwick, J.M. and Olewiler, N.D. 1998. The Economics of Natural Resource Use. Addison-Wesley Educational Publisher Inc. Reading, Massachussetts.

Haryadi dan Setiawan, B. 2002. Penyusunan IndikatorIndikator Keberlanjutan Kota di Indonesia (Indicators of Sustainable Cities for Indonesia). Manusia dan Lingkungan Hidup, Vol. IX, No. 3, November 2002. Pusat Studi Lingkungan Hidup, Universitas Gadjah Mada, Yogyakarta. p. 115-125

Mikkelsen, B. 1999. Metode Penelitian Partisipatoris dan Upaya-Upaya Pemberdayaan. Sebuah Buku Pegangan bagi Para Praktisi Lapangan. Yayasan Obor Indonesia. Jakarta.

Pitcher, T.J. and Preikshot, D. 2001. RAPFISH : A rapid appraisal technique to evaluate the sustainability status of fisheries. Fisheries Research 49(3) : 255-270. Fisheries Center University of British Columbia. Vancouver.

Ruitenbeek, J. and Cartier, C. 1998. Rational expectation: Economic criteria and indicators for sustainable management of tropical forests. Occasional Paper No. 17. Center for International Forestry Research. Bogor, Indonesia.

Taryono, 2003. Analisis Ekonomi Kelestarian Sumberdaya Perikanan Laut Pantai Utara Jawa. Thesis Sarjana Strata 2 (Tidak dipublikasikan). Program Pascasarjana Institut Pertanian Bogor. Bogor. 192 pp. 